\title{
Exploring the Roles of Religious Beliefs to Value Mathematics Education: An Alternative to the Madrasa Reform?
}

\author{
Kamirsyah Wahyu ${ }^{1, *}$ \\ ${ }^{1}$ Universitas Islam Negeri Mataram, Mataram, Indonesia \\ "Corresponding author. Email: kwahyu@uinmataram.ac.id
}

\begin{abstract}
Religion is considered as the richest source of values, which guides individuals' decisions in various aspects of life, including instructional practices for teachers. This idea has given rise to some research that identifies the relationships between religious beliefs and teaching. This paper explores the roles of pedagogical principles in religion toward the development of teachers' pedagogical values and proposes a value-based approach comprising the principles as a catalyst to reform mathematics education in madrasa. Literature on Islamic pedagogy, teachers' personal religious beliefs and the connection to their beliefs in teaching, and values research are thoroughly reviewed following the procedures of a systematic review. The review reveals the importance of so-called religious-based pedagogical tenets to prepare prospective teachers and synthesize the ways to reform mathematics education in madrasa.
\end{abstract}

Keywords: Madrasa reform, Religious beliefs, Religious-based pedagogical tenets, Values-based approach.

\section{INTRODUCTION}

Religion and education are two essential aspects of human life. The two are inter-connected; some religions have specific views on education in general and schooling, including instructional practices in specific. For example, a prophetic pedagogical framework was proposed [1]. Besides that, religion has impacts on educational outcomes [2].

The relations between religion and education have been debating and studying over decades [3]. However, in the mathematics education field as a particular context, the topic has not obtained much attention from researchers. The reason might be that religion has nothing to do with what school subjects teachers teach or students learn, or mathematics itself is mainly considered not value-laden. In 1988, reference [4] discussed how religion could be either a cultural carrier or barrier in mathematics education. In a broader theme, mathematics and cultural aspects came to the surface [5]. Years after this, some researchers [6] inquired about the enactment of teachers' religious-based pedagogical values in the classroom. Science education has a different situation; related research has been established $[7,8]$ due to the fact that it has 'controversy' content, such as evolution in which the teaching of such content relates to teachers' religious backgrounds.

A fundamental question to begin with pertaining to the topic is how does religion or religious beliefs relate to mathematics education? Or in a more pragmatic way, how does it benefit mathematics teaching and learning? Interestingly, teachers' goals and decisions to enact certain pedagogies in classrooms are, to some extent, affected by their religious beliefs, as several studies found [6-11]. This answers the questions and opens an opportunity to improve mathematics education. That is to say, it is possible to see religious beliefs as capital to prepare mathematics teachers. Reference [6] suggests that mathematics teacher education considers future teachers' values, which are likely affected by their religious backgrounds.

Considering the roles played by the religious beliefs and lack of empirical research in mathematics education that involve (prospective) mathematics teachers with Islamic backgrounds, a research project was carried out to further understand how religious beliefs held by prospective mathematics teachers associate with their development of pedagogical values. This paper presents literature reviews of the project, specifically explicate an 
idea about religious-based pedagogical tenets (RPT) and its promising roles to facilitate the development of teachers' pedagogical values. Along with the reviews, the (conjectured) results of the project will be highlighted. Moreover, it discusses synthesizes of the reviews and conjectured implications of the project for mathematics education in the madrasa and teacher education in religious-based higher education.

\section{METHODS}

To explore the roles of religious beliefs underlying the project and propose the valued based-approach, a systematic literature review (SLR) was selected. After thoroughly reading and analyzing some sources on the literature review [12,13], six procedures of SLR were formulated and employed in the project; (1) determining the aims of SLR, (2) determining the research topics, (3) planning a literature search, (4) searching and screening the literature, (5) analyzing the screened literature, and (6) synthesizing the results of the analysis. Due to the page limitation for this paper (6 pages), each procedure can only be highlighted as follow.

The aim of SLR in the context of the project was to explore the roles of religious beliefs in teaching practices and propose an approach in the basis of the roles to reform mathematics education in madrasa. Following this, related research topics were identified; Islamic pedagogy, values in mathematics education, and the relationship between religious beliefs and teaching practices in mathematics and science education. The first topic is considerably wide; therefore, it is limited on instructional practices or pedagogy in Hadith and Qur'an. When planning the literature search, various types of references were included, such as books or journal articles in related fields. Moreover, online databases (Scopus, Web of Science, ERIC, and DOAJ) and search procedures, for example, keywords "personal religious beliefs" were also decided.

After the plan was set, the search was carried out using the databases and then the results, for example, 81 documents in Scopus, were screened. In the screening process, inclusion and exclusion criteria were determined. For instance, the 81 documents were sorted based on the subject area and source titles. Besides the criteria, the researcher's (reading) experiences on the topics was useful to narrow down the search results. For example, in mathematics education, research on the relation of religious beliefs to the teachers' beliefs in classroom practices was done by several names. In the fifth step, the screened literature was qualitatively analyzed focusing on the research questions or the aims of the SLR. The results of the analysis were synthesized in the form of the proposed values-based approach and the roles of the religious in teaching practices. This synthesis is used to support the need for and significance of new research [13].

\section{THE RESULTS OF REVIEW}

\subsection{Islamic Pedagogy}

This term seems strange to include in a mathematics education paper. It is a never-ending topic of research for related scholars. A full cover of the topic is neither the aim of the project nor this article. The definition of the term has not reached an agreement amongst scholars in the field. In short, the project refers to Islamic pedagogy as an Islamic perspective on education, including vision, stages of development, instruction, curriculum, assessment and evaluation, learning environment, the role of the teacher, and the role of the student [14]. In specific, the project focused on instruction, learning environment, students, and teachers.

The Qur'an, as the first and primary source of code of conduct for all Muslims, along with the hadith (a collection of traditions containing sayings and the daily practice of the Prophet Muhammad) implicitly and explicitly regard didactical practices [1]. In case of the nature of knowledge that should be acquired, the Qur'an specify the methodology which is inspired from Qs. An Nahl verse 125, i.e., the application of wisdom, application of beautiful preaching, and application of best possible techniques of debate [15].

Reference [16] argues that the curriculum in the Qur'an uses different methods of instruction to develop the individual as a whole in all aspects of life while granting freedom of choice. The curriculum has two-fold meanings; developing the person as a whole in all aspects of life, whether spiritual, social, or mental, and methods of instruction. For the first meaning, there are five education requirements in the Qur'an, namely application of knowledge, recognition of the self, intention, critical thinking, and spirituality. For the latter, the Qur'an uses different didactic methods to teach its followers, namely command, repetition, parables, storytelling, and demonstration. Each method refers to the different context of teachings and types of knowledge.

The hadith can be considered as data comprising teaching moments [1] that result in some prophetic principles of teaching and learning; building relationships, relevance, deep knowledge and understanding, differentiation, engagement, the authenticity of knowledge, and language precision. Other scholars such as [17] also formulate pedagogical principles. There are three themes of pedagogies based on the hadith; relational, mutual engagement, and conscious awareness.

The didactical principles sourced from the Qur'an and the hadith [1], [14-17] can be formulated as Religiousbased Pedagogical Tenets (RPT) to be employed in developing the pedagogical values (PVs) of prospective 
Table 1. Personal religious beliefs scale

\begin{tabular}{|l|l|c|l|}
\hline \multicolumn{1}{|c|}{ Scale } & \multicolumn{1}{|c|}{ Construct } & $\begin{array}{c}\text { Number of } \\
\text { Items }\end{array}$ & \multicolumn{1}{c|}{ Sample items } \\
\hline \multirow{3}{*}{$\begin{array}{l}\text { Personal religious } \\
\text { beliefs }\end{array}$} & $\begin{array}{l}\text { Religious-based pedagogical } \\
\text { tenets }\end{array}$ & 9 & $\begin{array}{l}\text { In Islam, critical thinking is required in } \\
\text { learning }\end{array}$ \\
\cline { 2 - 4 } & $\begin{array}{l}\text { Teachers in Islamic } \\
\text { perspectives }\end{array}$ & 4 & $\begin{array}{l}\text { In Islam, being a teacher is a noble } \\
\text { profession }\end{array}$ \\
\cline { 2 - 4 } & $\begin{array}{l}\text { Islamic perspective towards } \\
\text { mathematics }\end{array}$ & 4 & $\begin{array}{l}\text { Mathematics does not contradict } \\
\text { Islamic teachings }\end{array}$ \\
\hline
\end{tabular}

mathematics teachers (PMTs). The tenets also relate to widely accepted didactic methods in mathematics education, such as inquiry learning referring to a constructivist perspective. Table I shows the RPT scale developed in the project drawing from the three aforementioned pedagogies [17]. The scale has gone through exploratory factor analysis (EFA) and is currently followed up by confirmatory factor analysis (CFA) after the second stage of data collection from over 570 respondents.

\subsection{Values in Mathematics Education}

Reference [5] coined the notion of mathematics as a cultural phenomenon and proposed the field to consider the values in mathematics education. After the seminal work, many values-related studies emerged, for example, VAMP (Values and Mathematics Project) in Australia and VIMT (Values in Mathematics Teaching) in Taiwan in the 2000s, following by PVIMTE (Pedagogical Values in Mathematics Teacher Education) project [18] and the Third Wave Project [19]. These studies give rise to the third approach as the alternative to the cognitive and affective, namely the volitional approach [20]. The approach (values) accentuates teachers' and students' motivation and disposition to teach and learn, respectively, which reflect the notion of socioculturallybased values in mathematics education [19].

Values have been conceptualized differently in the mathematics education research domain [21-24]. The definition of values in the project refers to [23], which is perceived as a conative variable rather than affective one. There are three ways of considering values in mathematics education; values of mathematics education (mathematical values), values for mathematics education (mathematics educational values), and values through mathematics education (general education values) [25]. The values of, for, and through underline how values operate in mathematics education. For example, values for mathematics education is how teachers enact her/his values to support the effectiveness of mathematics teaching and learning. The project is an endeavor to investigate values for mathematics education or later conceptualized as pedagogical values.
Referring to the definitions of pedagogical values in the prior studies $[26,27,28]$, pedagogical values in this study is defined as the teacher's principles of teaching mathematics which are considered to be essential and pedagogically beneficial for his/her instructional practices in the classroom. The principles relate to goals and process of teaching and learning mathematics, which guide teacher's decision (choosing which involves cognition, prizing includes affective) whether or not implement certain pedagogies in teaching mathematics (action represents behavior). Pedagogical values are the product of valuing and represents personal characteristics (identities) of (prospective) mathematics teachers. The definition acknowledges (pedagogical) values as the conative variable. A framework was developed to examine the PMTs' pedagogical values referring to the criteria of values [26].

The values-related research provides a valuable and alternative perspective to understand the effectiveness of mathematics teaching and learning [25,28,29,30]. In short, the studies imply that if the teacher is able to be aware of or clarify and gain control over his/her values and align or negotiate his/her values in mathematics teaching, then it will support the effectiveness of mathematics teaching and learning [30]. It cannot be argued that teacher education plays a vital role in preparing future teachers, including the development of the teachers' values in mathematics teaching and learning [28] It is argued that that "...the more the student teachers are aware of the values professed, the higher the willingness that they will have to implement such values..." (p.67) [18]. Referring to [18,30], it is conjectured that if we support the PMTs to clarify and/or develop their PVs, then they will possibly have a higher chance to enact the values and be more flexible in their thinking and practices in teaching mathematics.

\subsection{Religious Beliefs and (Prospective) Teachers' Practices}

In grounded theory research, a model of personal religious beliefs was established [31]. It explains how the personal religious beliefs and experiences of science teachers influence their beliefs and practices. The study suggests that it was chiefly teachers' personal religious 
Table 2. Mathematics-related beliefs scale

\begin{tabular}{|c|c|c|c|}
\hline Scales & Construct & $\begin{array}{l}\text { Number of } \\
\text { Items }\end{array}$ & Sample items \\
\hline \multirow{2}{*}{$\begin{array}{l}\text { Beliefs in } \\
\text { mathematics }\end{array}$} & $\begin{array}{l}\text { Values-process- } \\
\text { application }\end{array}$ & 4 & $\begin{array}{l}\text { Mathematics relates to the context or daily } \\
\text { problems faced by people }\end{array}$ \\
\hline & Formalism-scheme & 5 & Mathematics is free-value such as honesty \\
\hline \multirow{2}{*}{$\begin{array}{l}\text { Beliefs in } \\
\text { teaching and } \\
\text { learning } \\
\text { mathematics }\end{array}$} & $\begin{array}{l}\text { Contemporary- } \\
\text { constructivist-social }\end{array}$ & 8 & $\begin{array}{l}\text { In teaching and learning mathematics ... } \\
\text { Students collaborate with the teacher and } \\
\text { other students in a problem-solving activity }\end{array}$ \\
\hline & $\begin{array}{l}\text { Traditional-transmission- } \\
\text { information processing }\end{array}$ & 7 & $\begin{array}{l}\text { In teaching and learning mathematics ... } \\
\text { Students memorize symbols and formulas }\end{array}$ \\
\hline
\end{tabular}

beliefs and experiences that shaped their beliefs and practices. Following this, a further study involving mathematics teachers was carried out [11], aiming at investigating perceptions of mathematics teachers with different religious backgrounds on the relationship between their personal religious beliefs and their beliefs about teaching and learning. It was found that the different religions (Christian, Christian with a profound influence of Confucianism, and Buddhist) share some common values that influence the teachers' beliefs about mathematics teaching and learning and education in general. Although religion is a rich belief system, only a portion of their religious beliefs guide their teaching. The study empirically showed that their personal religious beliefs align with their beliefs in mathematics instructional practices.

Personal Religious Beliefs (PRB) is “...the views, opinions, attitudes, and knowledge constructed by a person through interaction with his/her socio-cultural context through his/her life history and interpreted as having their origins in religion... (p.1608)" [31]. The project follows this definition and specified three components of the PRB; PMTs' views about pedagogical tenets in their religion (RPT), the position of teachers in their religion, and their religion's perspectives toward mathematics. As it was asserted [31] that such study, including the project, is not to examine the influence of Islam as a religion on teachers' beliefs and practices. Instead, it is the influence of teachers' understanding and interpretation of their religious principles on the instructional practices and the extent to which the teachers' views directly or indirectly relate to their religion.

The project followed up the prior related studies [11,31] with some distinctions. Firstly, prior studies $[10,31,32]$ mainly involved in-service mathematics teachers. The current project had prospective teachers as the participants. Certainly, there are some differences between the teachers regarding teaching experiences, interpretations of the didactical principles from religion, beliefs, and developed competencies. The participants in the project even have not had considerably long teaching experiences. These will possibly affect their degree of clarification regarding teaching and learning of mathematics. For example, besides the PRB scale, the project also developed two other scales: mathematics beliefs as well as mathematics teaching and learning beliefs, and analyzed using factors analysis. The inservice teachers' interpretations of the items of the scales will be influenced by their longstanding teaching practices.

Secondly, the above studies were mainly qualitative. The project was a mixed-methods; a scale development ended with a structural equation modeling to examine the relationship between the PRB scale and the mathematicsrelated beliefs scales (Table II), following a qualitative multiple cases study of some selected PMTs in their teaching practices program in order to identify to what extent their PRB shape their pedagogical values. The implications of examining the relation between PMTs' PRB and their mathematics-related beliefs are explicated in the next part.

\section{SYNTHESIS FOR MADRASA REFORM}

This part focuses on the synthesis and implications of the SLR and the current project regarding the development of (prospective) mathematics teachers' PVs and the relationship between teachers' PRB and developed PVs towards the (quality of) instructional practices. The synthesis, hereby formulated as a valuesbased approach in Fig.1, are expected to be an alternative view on the attempts to reform madrasa, especially in mathematics education.

The approach is built upon the model of the lived space of mathematics learning $[33,34]$. The model explains that the space of students' outcomes is the result 
of the learning environment or the space they live in. The teachers shape the lived space.

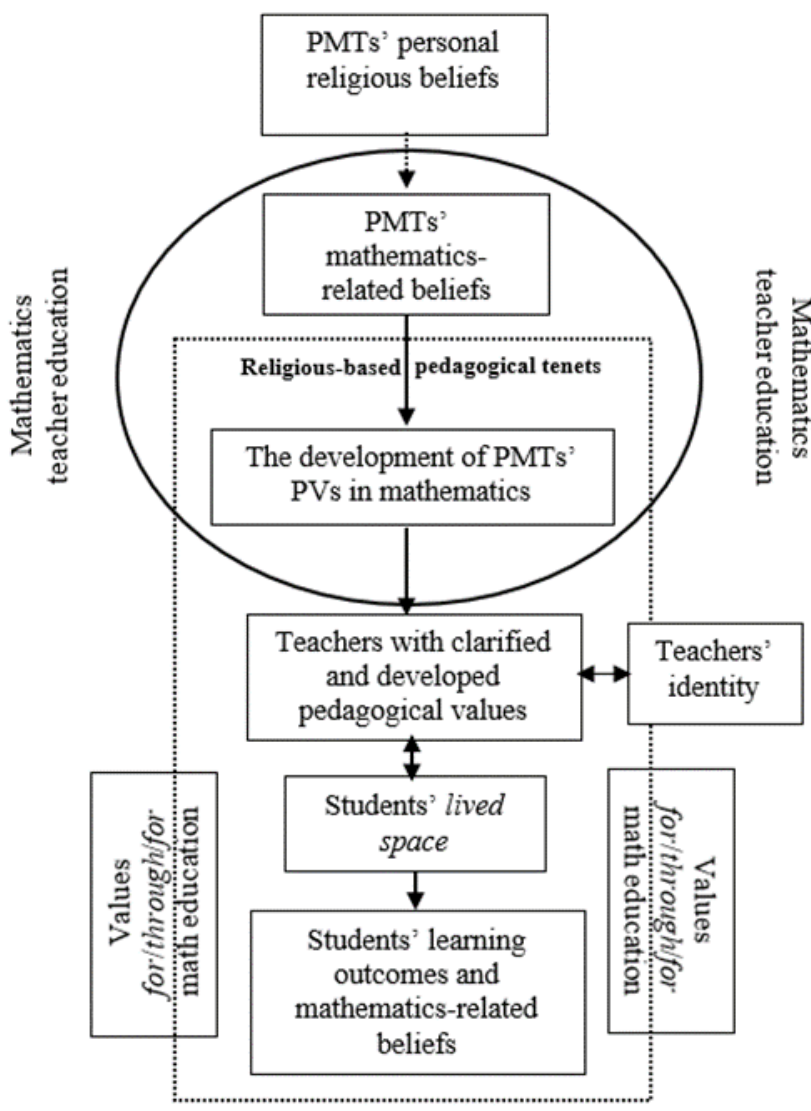

Figure 1 A proposed values-based approach to reform mathematics education in madrasa.

\subsection{Mathematics Education in Madrasa}

Little is known about the development and progress of mathematics education in madrasa or pesantren in Indonesia since there has not been any systematic research and publications available to the public. Specifically, what characterizes mathematics education in these religious-based institutions compared to public schools. The apparent difference is regarding some additional Islamic subjects taught in the madrasa, and all students have the same religion. Indeed, in terms of religious backgrounds, they are homogeneous, but they might come from different local cultures. Akin to the students, the teachers also have similar backgrounds regarding religion. Madrasa and public schools are under the same curriculum issued by the ministry of education, culture, research and higher education (MoECRHE), albeit madrasa is under the management of the ministry of religious affairs (MoRA). This sounds a bit complicated.

Since both madrasa and public schools implement the same curriculum, to some extent, they have common orientations or programs. For example, the character education (CE) program should be implemented in all schools and madrasa. To another extent, madrasa as an educational institution is characterized by policies from MoRA and its nature. In the first case, since currently MoRA focus on the issues of religious moderation such as tolerance, radicalism, gender, equality, etc. Madrasa is expected to be in the frontline to prevent and mitigate those issues amongst young people. In the second case, the madrasa is perceived as 'special' schools that teach more religious content. Indeed, students who graduated from madrasa are not merely good at mathematics or science, but also have good character. The characteristics represent the institutional values of madrasa [35].

Considering the characteristics, the questions are: How do mathematics teaching and learning facilitate the achievement of the goals? How do teachers educate students in mathematics classrooms so that the students are aware and being critical of the issues and embrace good values? How does teacher education prepare future teachers to fulfil related roles? There might be some programs or research, which address the questions. However, access to the results is possibly limited. Some parts of the questions have been reviewed, but representative answers are yet obtained [36]. The proposed values-based approach acknowledges the questions- all of which are grounded in teacher education as foundation. The third question will be discussed later.

The answers to the first two questions are likely not found in the 'mainstreaming' or 'conventional' classroom practices. The social turn in mathematics education research results in the emergent of alternative perspectives or issues of mathematics teaching such as values [5], critical mathematics education [37], or social justices [38]. For example, the students were provided with some tasks relating to the corona virus to elicit their critical mathematics consciousness [39]. Another example is that a mathematics teacher reflects on her classroom practices when promoting values like respect through JEDI (justifying, essaying, declaring, identifying) approach [40]. These two examples are the lived spaces the teachers create for their students so that, for instance, the students after learning mathematics are developing a sense of respect for the surrounding diversity.

\subsection{Teacher Education}

Teacher education plays a vital role in preparing prospective teachers. It is where the future teachers develop their knowledge, values and identity. That is to say, if we would have teachers who are capable of transforming their students to be active citizens [41] then teacher education programs should be set to that direction. There have been three prevalent approaches in teacher development; the development of knowledge, the construction of beliefs, and conceptual changes involving the intertwined of knowledge, beliefs, context. It is argued that the approaches have not considered a crucial 
issue for mathematics teachers concerning the nature of being a teacher; the teachers are developing their pedagogical identities to become the teachers that they value most. Therefore, the development of (pedagogical) identities and the transition of values ought to be considered as an additional approach [42]. Following this fourth, the values-based approach is proposed. As stated earlier, the third question places a foundation for the preceding questions. The elaboration of Fig.1. is as follows.

When enrolling in teacher education programs, PMTs bring in their PRB and mathematics-related beliefs accumulated from their experiences either at schools or out-schools, including informal education or family. Prior studies have proved that teachers' religious beliefs affect their pedagogical beliefs and practices in the classrooms. Therefore, the project identified their PRB, mathematics-related beliefs, and quantitatively examined the relation of their beliefs to gain further empirical evidence. If the result shows that, in the context of PMTs who have not had teaching experiences, PRB associate with their mathematics-related beliefs (positively), then the RPT has the potential to be utilized as an alternative or complement to the existing Western pedagogy in mathematics education. Since RPT is rooted in their religions, they might hold it 'tighter' than the other pedagogies. By way of example, in teaching Islam to people, the Prophet Muhammad promoted deep knowledge and understanding [1]. As he/she is a true admirer and follower of the Prophet, the pedagogical principle will be accepted and highly likely implemented as doing that will give him/her a reward. Thus, RPT is feasible to develop their PVs. The process of developing the PMTs' PVs is not easy as it may seem in Fig.1. A careful design of teacher education programs, especially curriculum, is fundamental. For instance, to support educational programs pertaining to the first and second question, PMTs firstly need to value that mathematics is not a free-value subject, and teaching mathematics can help students to be active citizens. To develop such values, related RPT and value-loaded activities [43] have to be brought in. Once the PVs are clarified and developed or also called beliefs in action, the teachers are ready to shape the students' lived space.

\section{CONCLUSION}

This paper proposes a values-based approach, depicted in Fig.1, as an alternative to reform mathematics education in madrasa. The approach is grounded in theories about values in mathematics education, especially the importance of pedagogical values to guide teachers' instructional practices, and empirical evidence on the relationship between teachers' PRB, beliefs in mathematics teaching and learning, and classroom practices. It strongly acknowledges the underlying characteristics of the madrasa. Reforming mathematics education is not an easy task. One of the challenges is to facilitate research and connect it with practices. It is too often educational policies are not informed by research, and there is a gap between the research and the practices [34].

\section{REFERENCES}

[1] M. Abdullah, a prophetic pedagogical framework for islamic schools, Paper presented at the 3rd ICEMS 2017, 2017, [Online]. Available: https://www.atlantispress.com/article/25895142.pd f

[2] C.C. Jett, Many are called, but few are chosen: The role of spirituality and religion in the educational outcomes of "chosen" African American male mathematics majors, The Journal of Negro Education 7(3) (2010) 324-334.

[3] I. Diallo, Introduction: The interface between Islamic and Western pedagogies and epistemologies: Features and divergences, International Journal of Pedagogies and Learning 7(3) (2012) 175-179. DOI: https://doi.org/10.5172/ijpl.2012.7.3.175

[4] M.E. Jurdak, Religion and language as cultural carriers and barriers in mathematics education-Revisited, Journal of Humanistic Mathematics, 4(2) (2014) 47-57. Doi: https://doi.org/10.5642/jhummath.201402.05

[5] A. Bishop, Mathematical Enculturation: A Cultural Perspective on Mathematics Education. Springer, 1991.

[6] Y.C. Leu, The enactment and perception of mathematics pedagogical values in an elementary classroom: Buddhism, Confucianism, and curriculum reform, International Journal of Science and Mathematics Education 3(2) (2005) 175-212. DOI: https://doi.org/10.1007/s10763-004-3371-5

[7] T. Stolberg, The religio-scientific frameworks of pre-service primary teachers: An analysis of their influence on their teaching of science, International Journal of Science Education 29(7) (2007) 909-930. DOI: https://doi.org/10.1080/09500690600924934

[8] N. Mansour, Science teachers' views of science and religion vs. the Islamic perspective: Conflicting or compatible?, Science Education 95(2) (2010) 281309. DOI: https://doi.org/10.1002/sce.20418

[9] Y.C. Chan, N.Y. Wong, Y.C. Leu, Do teachers with different religious beliefs hold different values in math and math teaching, in: T.Y. Tso (Ed.), The proceedings of the 36th Conference of the International Group for the Psychology of 
Mathematics Education, Vol. 4, Taipei, Taiwan, 2012, pp.254.

[10] Y.C. Leu, Y.C, Chan, N.Y. Wong, The relationships between religious beliefs and teaching among mathematics teachers in Chinese Mainland, Taiwan and Hong Kong, in: L. Fan, N.Y. Wong, J. Cai, S. Li (Eds.), How Chinese Teach Mathematics: Perspectives from Insiders, Singapore: World Scientific Publishing Co., 2015, Ch. 21, pp. 653701.

[11] Y.C. Chan, N.Y. Wong, Worldviews, religions, and beliefs about teaching and learning: Perception of mathematics teachers with different religious backgrounds, Educational Studies in Mathematics 87(3) 251-277. DOI: https://doi.org/10.1007/s10649-014-9555-1

[12] C. Hart, Doing a Literature Review: Releasing the Research Imagination. London: SAGE, 2018.

[13] A. Fink, Conducting Research Literature Reviews: From the Internet to Paper. London: SAGE, 2019.

[14] N.A. Memon, M. Alhashmi, Islamic pedagogy: Potential and perspective, in: Abdalla, D. Chown, M. Abdullah (Eds.), Islamic Schooling in the West, MPalgrave Macmillan, Cham. 2018, ch.9, pp.169194. DOI: https://doi.org/10.1007/978-3-31973612-9_9

[15] Q. Sultana, Philosophy of education: An Islamic perspective, Philosophy and Progress 51(1-2) (2014) 9-36. DOI: https://doi.org/10.3329/pp.v51i12.17676

[16] S. Risha, Education and curricular perspectives in the Quran, Ph.D dissertation, Arizona State University, Arizona, 2013. [Online]. Available: https://repository.asu.edu/attachments/125823/cont ent/Risha_asu_0010E_13362.pdf

[17] C. Alkouatli, Pedagogies in becoming Muslim: Contemporary insights from Islamic traditions on teaching, learning, and developing, Religions 9(11) (2018) 367-386. DOI: https://doi.org/10.3390/re19110367

[18] C.Y. Wang, Reconsidering the category framework for describing mathematics teachers values, Journal of Korean Society in Mathematics Education 15(1) (2011) 59-68. DOI: https://doi.org/10.7468/jksmed.2011.15.1.059

[19] W.T. Seah, N.Y. Wong, What students value in effective mathematics learning: a 'Third Wave Project' research study, ZDM Mathematics Education 44(1) (2012) 33-43. DOI: https://doi.org/10.1007/s11858-012-0391-4
[20] W.T. Seah, N.Y. Wong, Thematic issue on 'Values in East Asian Mathematics Education-The Third Wave', ZDM Mathematics Education, 44(1) (2012) 1-2, 2012. DOI: https://doi.org/10.1007/s11858012-0402-5

[21] A. Bishop, W.T. Seah, C.Chin, Values in mathematics teaching-The hidden persuaders?, in: A.J. Bishop et al., (Eds.), Second International Handbook of Mathematics Education, Dordrecht: Springer, 2003. pp. 717-765.

[22] M.S. Hannula, Looking at the third wave from the West: framing values within a broader scope of affective traits, ZDM Mathematics Education 44(1) (2012) 83-90. DOI: https://doi.org/10.1007/s11858012-0410-5

[23] W.T. Seah, Improving mathematics pedagogy through student/teacher valuing: Lessons from five continents, in: G. Kaiser, H. Forgasz, M. Graven, A. Kuzniak, E. Simmt, B. Xu (Eds.), Invited Lectures from the 13th International Congress on Mathematical Education, Switzerland: Springer, 2018, pp.561-580. DOI: https://doi.org/10.1007/978-3-319-72170-5_31

[24] M.E. Carr, Student and/or teacher valuing in mathematics classrooms: Where are we now, and where should we go? In: P. Clarkson, W.T. Seah, J. Pang (Eds.), Values and Valuing in Mathematics Education, Springer, 2019, pp. 25-52.

[25] W.T. Seah, Values in the mathematics classroom: Supporting cognitive and affective pedagogical ideas, Pedagogical Research 1(2) (2016) 53-57. DOI: https://doi.org/10.20897/lectito. 201653

[26] L.E. Raths, M. Harmin, S. Simon, Selections from values and teaching, in: P.F. Carbone (Ed.), Value Theory and Education, Malabar: Krieger, 1987.

[27] C. Chin, F.L. Lin, A case study of a mathematics teacher's pedagogical values: Using a methodological framework of interpretation and reflection, in: Proceedings of the National Science Council Part D: Mathematics, Science. and Technology Education, 2000, pp.90-101.

[28] C. Chin, Y.C. Leu, F.L. Lin, Pedagogical values, mathematics teaching, and teacher education: Case studies of two experienced teachers," in: F.L. Lin, T.J. Cooney (Eds.), Making Sense of Mathematics Teacher Education, Springer, 2001, pp.247-269.

[29] Q. Zhang, T. Barkatsas, H.Y. Law, Y.C. Leu, W.T. Seah, What primary students value in mathematics learning: A comparative analysis among the Chinese mainland, Hong Kong, and Taiwan, International Journal of Science and Mathematics 
Education 14(5) (2016) 907-924. Doi: https://doi.org/10.1007/s10763-014-9615-0

[30] P. Kalogeropoulos, J.A. Russo, P. Clarkson, Special Issue: Exploring educator values alignment strategies in an intervention context: The emergence of the Beacon strategy, ECNU Review of Education (2020) 1-22. DOI: https://doi.org/10.1177/2096531120923127

[31] N. Mansour, The experiences and personal religious beliefs of Egyptian science teachers as a framework for understanding the shaping and reshaping of their beliefs and practices about science-technologysociety (STS), International Journal of Science Education 30(12) (2008) 1605-1634. DOI: https://doi.org/10.1080/09500690701463303

[32] Y.C. Chan, N.Y. Wong, A multiple case study of teachers referring to their own religious beliefs in mathematics teaching, International Journal of Children's Spirituality 21(3-4) (2016) 243-255. DOI:

https://doi.org/10.1080/1364436X.2016.1251398

[33] N.Y. Wong, F. Marton, K.M. Wong, C.C. Lam, The lived space of mathematics learning, The Journal of Mathematical Behavior 21(1) (2002) 25-47. DOI: https://doi.org/10.1016/S0732-3123(02)00101-3

[34] Q. Zhang, N.Y. Wong, Beliefs, knowledge and teaching: A series of studies about Chinese mathematics teachers, in: L.Fan, N.Y. Wong, J. Cai, S. Li (Eds.), How Chinese Teach Mathematics: Perspectives from Insiders, Singapore: World Scientific Publishing Co., 2015, Ch. 15, pp. 457492.

[35] A.J. Bishop, Educating student teachers about values in mathematics education, in: Making Sense of Mathematics Teacher Education, Holland: Kluwer Academic Publishers, 2001, pp. 233-246.

[36] S. Mahfudy, K. Wahyu, Mauliddin, L. Sucipto, E. Evendi, S. Irpan, Characters and values in mathematics teaching and learning: A review of research in Indonesia, Beta: Jurnal Tadris Matematika 12(1) (2019) 60-81. DOI: https://doi.org/10.20414/betajtm.v12i1.237

[37] A. Andersson, R. Barwell, Applying Critical Mathematics Education, The Netherlands: Brill, 2021. DOI: https://doi.org/10.1163/9789004465800

[38] E. Gutstein, Reading and Writing the World with Mathematics: Toward a Pedagogy for Social Justice. Taylor \& Francis, 2006.

[39] M. Stephan, J. Register, L. Reinke, C. Robinson, P. Pugalenthi, D. Pugalee, People use math as a weapon: critical mathematics consciousness in the time of COVID-19, Educational Studies in Mathematics (2021) 1-20. DOI: https://doi.org/10.1007/s10649-021-10062-Z

[40] R. Lowrey, Teaching mathematics: The JEDI way, VINCULUM 58(2) (2021) 6-7.

[41] K. Maass, M. Doorman, V. Jonker, M. Wijers, Promoting active citizenship in mathematics teaching, ZDM Mathematics Education 51(6) (2019) 991-1003. DOI: https://doi.org/10.1007/s10763-021-10182-1

[42] C. Chin, Conceptualising pedagogical values and identities in teacher development: A comparison of Taiwanese and Australian mathematics teachers, in: F.K.S. Leung, K.D. Graf, F.J. Lopez-Real (Eds.), Mathematics Education in Different Cultural Traditions-A Comparative Study of East Asia and the West, Boston, MA: Springer, 2006, Vol. 9, pp.537-547.

[43] C. Chin, F.L. Lin, Value-loaded activities in mathematics classroom, in: M. van den HeuvelPanhuizen (Ed.), The Proceedings of the PME 25 Conference, Utrecht: Utrecht University. 2001, Vol. 2, pp.249-256. 